\title{
Music Subculture versus Class Revolutionaries: Czech Antifascism in the Postsocialist Era
}

\author{
Ondřej Daniel \\ Department of Media Studies, Metropolitan University Prague, Prague - \\ Strasnice, Czech Republic \\ ondrej.daniel@mup.cz
}

\begin{abstract}
With its roots in the political, economic and social changes of 1989/199o, the Czech antifascist movement was initially characterized by its young supporters, who came mostly from subcultural and anarchist circles. When violent far-right skinheads increased their attacks in the country between 1990 and 1992, local antifascists were the main group to physically confront them. Three decades later, as a result of generational and tactical changes, Czech antifascists' agenda is largely at odds with the class politics that drive important parts of the anarchist movement. At the same time, the antifascist movement retains some subcultural traits that have become depoliticized. Its strategy is now limited to monitoring far-right activists online and running cultural events. This study analyzes internal debates over the antifascist movement's positions and reflects on their development over time.
\end{abstract}

\section{Keywords}

Czech Republic - antifascism - postsocialism - militancy - anarchism - subculture

Recent research into militant antifascist groups has questioned whether they have a role beyond physical actions such as gang violence, blockades, picketing and counter-demonstrations. ${ }^{1}$ It would be a mistake to apply this approach to the Czech antifascists who were active in the postsocialist period. The

$1 \quad$ See e.g. Nigel Copsey, 'Militant Antifascism: An Alternative (Historical) Reading,' Society 55 (2018): 243-247, https://doi.org/10.1007/s12115-018-0245-y.

(C) ONDǨEJ DANIEL, 2020 | DOI:10.1163/22116257-09010008

This is an open access article distributed under the terms of the prevailing CC-BY-NC license at the time of publication. 
complex structure of the Czech antifascist movement is clear from its participants' rich textual output, some of which provides the source material for this study. In the case of Ladronka, the Prague squat that served as a social hub for a broad network of non-conformists in the early postsocialist years, the residents fell into two distinct camps: intoši [nerds] and palaši [fighters]. ${ }^{2}$ My research draws on the texts of individuals who might place themselves in the first group: the 'brains' of the antifascist movement. My primary goal is to analyze ideological shifts in Czech antifascism and their connection with tactical and generational changes in the movement. Since the group Antifašistická akce [AFA: Anti-Fascist Action] dominated postsocialist Czech antifascism, I focus on its self-conception, as expressed by movement intellectuals. At the same time, I attempt to locate its motivations somewhere on the spectrum between lifestyle choices and anti-capitalism.

The debate about the self-conception of Czech antifascists connects with simultaneous discussions in the anarchist movement that has been a pillar of the Czech antifascist movement. At the beginning of the 2010s, research on local social movements followed a paradigm from security studies including a rather controversial concept of extremism. ${ }^{3}$ Nevertheless, Martin Bastl offered a more nuanced analysis of the evolution of the Czech antifascist movement, noting especially its attenuating ties to Marxism and revolutionary anarchism. ${ }^{4}$ In what follows, I draw on this analysis and extend it by applying the notion of a subculture, which seems to be increasingly relevant to antifascism. In the context of Czech postsocialist subcultures, several works have opened up the debate, including the research of Jan Charvát, Bob Kurrík and others on subcultural politics and my own research on subcultural violence and its relation to the mainstream. ${ }^{5}$ Earlier research by Ondřej Císař and Martin Koubek highlighted local contexts in which antifascism was entwined with a larger hardcore/punk scene, pointing to the city of Brno as an example. ${ }^{6}$

2 Arnošt Novák and Bob Kuřík, 'Rethinking Radical Activism: Heterogeneity and Dynamics of Political Squatting in Prague after 1989,' Journal of Urban Affairs 42, no. 2 (2019): 1-19, https:// doi.org/10.1080/07352166.2019.1565820.

3 Martin Bastl, Miroslav Mareš, Josef Smolík and Petra Vejvodová, Krajní pravice a krajní levice $\nu \check{C} R$ (Praha: Grada, 2011).

4 Martin Bastl, 'Antifašistická akce: Od subverze k vigilantismu?' Rexter 2 (2010): 1-41.

5 Jan Charvát, Bob Kuř́k a kol., Mikrofon je naše bomba: Politika a hudební subkultury mládeže $v$ postsocialistickém Česku (Praha, Togga 2018); Ondřej Daniel, Násilím proti 'novému biedermeieru': subkultury a většinová společnost pozdního státního socialismu a postsocialismu (Př́bram: Pistorius \& Olšanská, 2016).

6 Ondřej Císař and Martin Koubek, 'Include 'em all? Culture, Politics and a Local Hardcore/ Punk Scene in the Czech Republic', Poetics 40 (2012): 1-21, https://doi.org/10.1016/j. poetic.2011.12.002. 
In this study, I am less interested in how antifascist practices relate to mainstream politics and society. As such, I do not include mainstream media or police reports on extremism among my sources. I also leave aside the texts of other autonomous and anarchist movements that might help us examine the antifascist movement in relation to broader social movements. Rather, my goal is to analyze the development of the Czech antifascist movement over almost thirty years of postsocialism with a focus on its class and subcultural consciousness. I do this by drawing on materials produced by AFA, which was arguably the most important antifascist force in the period.

Given the rich scholarship that explores the intersection of subcultures and class, these two frameworks are clearly not mutually exclusive. ${ }^{7}$ This tension, however, stems from the emic perspectives of AFA intellectuals along with a 'post-subcultural' discourse that links subcultural experience increasingly to individual lifestyle or scene choices rather than class. ${ }^{8}$ In this context, observers in different fields of the social sciences and the humanities have raised concerns about the postsocialist silencing of class. ${ }^{9}$ While Czech antifascism after 1989/1990 was based to some degree on a blank slate after the fall of the communist dictatorship, research on earlier modes of antifascism has helped identify key antifascist tropes, particularly from Germany and Italy. ${ }^{10}$ Both

7 I refer especially to the research tradition based on the work of the Birmingham Centre for Contemporary Cultural Studies. See, e.g., Dick Hebdige, Subculture: The Meaning of Style (London: Routledge 1979). For a more recent contribution, see Sumi Hollingworth, 'Performances of Social Class, Race and Gender Through Youth Subculture: Putting Structure Back in to Youth Subcultural Studies,' Journal of Youth Studies 18, no. 10 (2015): 1237-1256, https://doi.org/10.1080/13676261.2015.1039968.

8 See, e.g. Andy Bennett, 'The Post-Subcultural Turn: Some Reflections 10 Years On,' Journal of Youth Studies 14, no. 5 (2011): 493-506.

9 Liviu Chelcea and Oana Druţă, 'Zombie Socialism and the Rise of Neoliberalism in Postsocialist Central and Eastern Europe,' Eurasian Geography and Economics 57, no. 4-5 (2016), 521-544, https://doi.org/10.108o/15387216.2016.1266273; David Ost, 'Stuck in the Past and the Future: Class Analysis in Postcommunist Poland,' East European Politics and Societies and Cultures 29, no. 3 (2015): 610-624; Philipp Ther, Die neue Ordnung auf dem alten Kontinent: Eine Geschichte des neoliberalen Europa (Berlin: Suhrkamp 2014).

10 For details of the German context, see Antonia Grunenberg, 'Antitolitarianism Versus Antifascism: Two Legacies of the Past in Germany,' German Politics \& Society 15 (1997): 7690; and Anson Rabinbach, 'Introduction: Legacies of Antifascism,' New German Critique 67 (1996): 3-17. For reflections on Italy, see Giovanni Orsina, 'Antifascism, Anticommunism, Antipolitics: Delegitimation in Berlusconi's Italy', Journal of Modern Italian Studies 22 (2017): 7-26, https://doi.org/10.108o/1354571X.2017.1267978; and Stéfanie Prezioso, 'Antifascism and Anti-totalitarianism: The Italian Debate', Journal of Contemporary History 43 (2008): 555572, https://doi.org/10.1177/oo22009408095415. 
the history of political violence in western Germany ${ }^{11}$ and the German Die Autonomen [autonomist] movement ${ }^{12}$ strongly influenced Czech antifascism. As a result, the latter tended to have a revolutionary mission that understood antifascism as the first step in the radical re-building of society.

The methodology of this study relies on textual analysis with a focus on diachronic changes and developments. As well as examining print materials from AFA's early years and its subsequent online output, I make use of elements of participant observation. I took part in May Day festivals and antifascist events in Prague in 2008 and 2009 and was even more actively involved in the local initiative Brno blokuje [Brno Blockade] in 2011.

This work begins by examining the context of postsocialist political street violence along with the main Czech antifascist actors and specific local features. I then describe the formation of AFA in response to police violence and attempt to make sense of the group's anti-state leanings. The core of this study consists of an analysis of antifascist discourse with a particular focus on whether antifascist strategies are better understood as part of a wider revolutionary project or the expression of different subcultural scenes. Finally, I describe the practical implementation of strategic and tactical changes in the Czech antifascist movement by drawing on participant observation.

\section{'Kill the Motherfucking Skinheads!'}

This study considers the experiences of the relatively large cohort of Czech population known as Husákory děti [Husák's children] who were born in the late 1970s and grew up in the early 199os. These early postsocialist years were a time of heightened tension: amidst the euphoria over the fall of communism, there was news of not only the dismantling of the Czechoslovak federation but conflict in the Persian Gulf and, even more critically, the break-up of Yugoslavia and the Soviet Union. The result was sweeping economic, social and cultural changes: greater freedom and the democratization of public life; ongoing privatizations; a rise in social precarity and the increased availability of illegal drugs and pornography. This was also the context in which aggressive far-right skinheads began to mimic their German peers who had been active

\footnotetext{
11 Alexander Sedlmaier, Consumption and Violence: Radical Protest in Cold-War West Germany (University of Michigan Press, 2014).

12 Geronimo, Fire and Flames: A History of the German Autonomist Movement (Oakland: PM Press, 2012).
} 
since the late 1980s. Beginning around 1990, their Czech counterparts carried out many hate crimes. While the actual number of these attacks is uncertain because of the lack of clear metrics and official police statistics, AFA estimates that there were around one thousand hate crimes in the first half of the 199os alone based on research by local anti-racist non-profit Hnutí za občanskou svobodu a toleranci [Movement for Civic Freedom and Tolerance]. Even if this figure is inflated, the violence itself is indisputable. ${ }^{13}$ Moreover, as the Roma activist site Romea.cz points out, the reporting of far-right violence is problematic because law enforcement did not recognize these attacks as crimes until the late 199os. ${ }^{14}$

This far-right violence was nevertheless a daily reality for many young people in the 199os. As well as smaller far-right groups and skinheads, a fairly prominent far-right party Sdružení pro republiku - Republikánská strana Československa [SPR-RSČ; Rally for the Republic - Republican Party of Czechoslovakia] drew concern from antifascists in these early postsocialist years. ${ }^{15}$ While only a handful of far-right groups identified as openly fascist in the 1990s, this trend had shifted by the mid-199os as more far-right skinheads embraced neo-Nazism. In this context, the antifascists opposed a range of groups for whom at least the glorification of the nation and state was a common denominator. Antifascist activists were mostly recruited from the non-conformist subcultures that together with the Roma were the prime targets of far right violence. The main focus of their discord with the far right was an incompatible world view often expressed through terms like 'the individual' and 'liberty'.

Anarchist punks, in particular, were instrumental in organizing the first groups to oppose the far right. They were joined by other young members of alternative scenes, including relatively new ones that had emerged among Czech young people at the end of 1980s (for example, skateboarding and hardcore, grunge and hip-hop fan scenes) as well as some remnants of former underground and alternative groups under socialism. The transfer of cultural, ideological and practical know-how from Germany and Poland was also vital in this era. During the late 198os, some punk fanzines described clashes between punks and skinheads at music festivals in Poland. The Polish slogan 'Zabić skina - skurwysyna! ['Kill the motherfucking skinheads!'] was subsequently

13 Antifa news 4 (1997), 3.

14 Rasově motivované násilí v ČR po roce 1989,' Romea.cz, 20 March 2007, http://www.romea. cz/cz/zpravy/rasove-motivovane-nasili-v-cr-po-roce-1989, accessed July 2019.

Antifa news 2 (1996); Antifa news 4 (1997). 
adopted by some Czech punks ${ }^{16}$ even as others from local punk scenes assisted far right skinheads in anti-Roma attacks in northern Bohemia and elsewhere. ${ }^{17}$

By the early 199os, militant German autonomism had come to influence the anarchist groups who promoted antifascism. ${ }^{18}$ When some three hundred far right skinheads attacked punks after a tense stand-off at a Prague concert in the spring of 1991, violent clashes ensued..$^{19}$ The violence erupted again in May of that year at Prague Exhibition Grounds where anarchists were protesting wasteful government spending. And it continued in March 1992 at a demonstration in the city center. Both sides attest that the conflict came to a head not long afterwards in a May Day 'battle' in Prague in $1992^{20}$ though there is some disagreement about what happened next. For the antifascists, the May Day showdown marked a victory in Prague through it did not negate the far right stronghold in other parts of the Czech Republic. In contrast, far right activist Filip Vávra acknowledges his side's defeat in the 1992 clash but notes that far right attacks continued in Prague even between 1992 and $1996 .{ }^{21}$

\section{'The Police Cover Up For the Fascists'}

Years of militant antifascism by grassroots anarchist and autonomist groups culminated in the birth of the Czech Antifašistická akce in 1996. As we have seen, the situation in Prague differed in important ways from that in other Czech regions, and even AFA acknowledged Prague's special position..$^{22}$ As such, despite AFA's gradual regional expansion, it is unclear whether it was ultimately a Prague-centered, Czech or Czechoslovak project. Northern Bohemia, in particular, had distinct concerns because of the widespread anti-Roma racism in the region and the local far right's early turn to neo-Nazism. In Brno too, the far right had an important street presence ${ }^{23}$ but antifascism provided

16 'Víkendové cypoviny: Hon na skinheads..., Punk.cz, 8 March 2009, http://www.punk.cz/ index.asp?menu=2198\&record=8803, accessed July 2019.

17 Filip Fuchs, Kytary a řev aneb co bylo za zdí (Brno: Papagájův Hlasatel, 2002).

18 Akce 15 (2011), 4; Akce 17 (2012), 2-5.

19 'AfA: Šestnáct let v první linii,' Antifa.cz, 3 April 20o6, http://antifa.cz/content/afa-sestnactlet-v-prvni-linii, accessed July 2019. This incident was also described in a recently published memoir by far-right activist Filip Vávra, Těžký boty to vyřěsej hned (Praha: Fiva, 2017). Akce 15 (2011), 4; 'Retro: 1. máj 1992,' Antifa.cz, 3 September 2009, https://antifa.cz/content/ retro-1-maj-1992, accessed July 2019.

21 Vávra, Těžký boty.

$22 \quad$ Akce 15 (2011), 4.

23 A-kontra 2 (2004). 
rare common ground across different hardcore/punk scenes. ${ }^{24}$ The picture in eastern Moravia was even more varied. In the small town of Otrokovice, for example, antifascists held key posts; the music group Edelweiss Piraten, which echoed the name of the well-known German antifascist group, also had its base there. ${ }^{25}$ Just twenty five kilometers away, however, the town of Uhersky Brod was a hotbed for the far right. Antifascist activists saw neighboring Slovakia as an even more complex case than the Czech Republic. They underlined the country's significant history of home-grown fascism ${ }^{26}$ and regular far-right violence even in the capital Bratislava. ${ }^{27}$ A Slovak group named Antifašistická akcia was formed in August $1995 .{ }^{28}$ Later, AFA's main magazine, Akce, and subsequently its website, antifa.cz would feature regular reports on the situation in Slovakia with the majority of these articles appearing in Slovak.

The main impetus for the founding of Czech AFA was a police raid on 4 May 1996 on Propast, a Prague club for punks and members of the antiracist skinhead group Skinheads Against Racial Prejudice (SHARP). ${ }^{29}$ SHARP had originated in the United States and United Kingdom in the second half of the 1980 os in response to the far-right's appropriation of the skinhead aesthetic. SHARP drew on the non-racist heritage of that style in the 196os, as linked to the ska music genre and the Fred Perry fashion brand. From the early 199os, SHARP began to attract more Czech young people although the number and influence of its adherents was small overall compared to those of far right skinheads. The May 1996 raid occurred during a benefit concert for an antifascist skinhead who had been imprisoned for attacking a far right activist in a nearby town. While the precise reasons for the police action remained hazy, it was alarmingly violent and left many people severely injured. This violence, in turn, led AFA to take a strong anti-police and anti-state line in its rhetoric and local actions. The police and the state were treated as enemies similar to the far right, and at many antifascist demonstrations, they were addressed as the 'Gestapo' or with the slogan 'Je to police, kdo fašisty kryje' ['It's the police covering up for the fascists']. This theme of police suppression of the antifascist movement in the Czech Republic, Slovakia, Germany and elsewhere was echoed across AFA materials particularly in the late 199os when memories of the Propost raid

\footnotetext{
24 Císař and Koubek, 'Include 'em all?'

25 Detlev Peukert, Die Edelweißpiraten: Protestbewegungen jugendlicher Arbeiter im Dritten Reich: Eine Dokumentation (Köln: Bund-Verlag, 1980).

26 Akce 12 (2006).

27 Akce 5 (2002), 6.

28 Antifašistický bulletin 1 (1995).

29 Akce 5 (2002), 8.
} 
were still vivid. ${ }^{30}$ But as late as the early 20oos, AFA denounced 'police spying' and the anti-extremism activities of state security services, demanding free speech even for fascists. ${ }^{31}$ At the International Monetary Fund and World Bank summit in Prague in September 2000, AFA accused police and the media of creating a moral panic around local demonstrations. It also began to highlight security as a pressing concern given the growing use of the internet, email and cellphones in the early 20oos:

Back under the Bolsheviks before 1989, who would've thought that there'd be six times more cops in this so-called democracy than there were in the old police state? That the cops could spy on us via our phones and raid our homes without a warrant? That the right to strike would be pared back again? That almost everyone would be carrying around a potential surveillance device like a cellphone? ${ }^{32}$

As well as appealing repeatedly for better mobile phone and online security,33 AFA condemned the mainstream media's coverage of its activities, which it claimed had endangered the organization by divulging personal information and giving intelligence to the police and the far right. Various journalists were singled out for failing to warn the individuals featured in their coverage. ${ }^{34}$ Others were charged with presenting a one-sided picture ${ }^{35}$ or trivializing far right violence. ${ }^{36} \mathrm{~A}$ final critique came along ideological lines: 'Although the media criticizes individual politicians, the basic premise of man's subjugation of man will never be challenged. ${ }^{37}$ Nevertheless, in 2007, AFA began to cooperate more with journalists. ${ }^{38}$ From the organization's perspective, the results were not always ideal and the criticisms of the media continued. AFA representatives objected vehemently, for example, to the coverage of an August 2011 incident leading up to a wave of anti-Roma rallies in northern Bohemia. ${ }^{39}$

According to the model introduced by the Czech political scientist Jan Charvát, the life cycle of far right social movements includes periods of activity

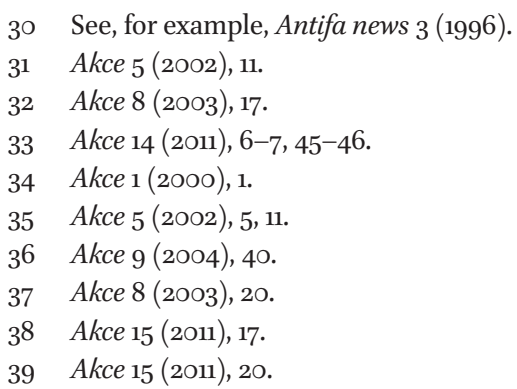


and inactivity. ${ }^{40}$ Charvát notes several peak periods for far right activities in the Czech context: during the early 199os, the late 199 os and the late 200os. AFA represented a response to this fascist violence. After the initial phase of grassroots violence in the early postsocialist years, the organization was driven to respond to the far right's resurgence in the late 199os. The threat became particularly clear with the emergence of Národní odpor [NO; National Resistance], an openly neo-Nazi party with branches in major Czech cities. AFA members organized demonstrations against rallies by NO and other far right entities including the fascist group Vlastenecká liga [the League of Patriots]. The biggest changes to AFA were, however, propelled by internal forces. In the first half of the 2000s, the organization established new links with a range of anarchist groups beginning with the anarcho-syndicalists. Around this time, it also adopted a new tactic: the organization of summer camps for activists. These camps resembled those traditionally run by leftist groups such as Trotskyists and anti-globalization activists, with programs of political presentations, cultural activities, group sports and walks.

\section{Subcultural or Class Politics?}

Over the almost three decades of the postsocialist era, Czech antifascists continued to locate themselves on the border between a subculture and a social movement. These two orientations were a regular source of conflict between the different strands of AFA. While the first strand sought an alliance among non-conformist young people, the second aimed for cooperation with workers and the creation of anarchist trade unions. At the same time, both groups remained militant and committed to physically confronting fascists. The turn to youth subcultures came under fire in a 2003 issue of Akce that appeared at a time when AFA was linked to the Federace sociálnich anarchistů [FSA; Federation of Social Anarchists]. Supporters of FSA's anarcho-syndicalism launched a scathing ideological attack on AFA activists with subcultural connections; their antifascist involvement was dismissed as a 'short-lived fashion trend. ${ }^{41}$ There was also some debate about drunkenness at AFA events like May Day 2003 in Bratislava, with critics putting the blame on punk louts. ${ }^{42}$ AFA's historical ties with autonomism prompted comparisons with the German

40 Jan Charvát, Současný politický extremismus a radikalismus (Praha: Portál, 2007): 141-156.

$41 \quad$ Akce 8 (2003), 1.

42 Akce $8(2003), 14$. 
Schwarze Block [Black bloc] scene. ${ }^{43}$ Even so, as the months passed, AFA organizers seemed to forget the criticisms of ties to music subcultures such as the anarchist punk and anti-racist skinhead scenes. Instead, they increasingly promoted martial arts and associated streetwear. These efforts persisted even as the movement tried to integrate criticisms that its culture was too macho and focused on the use of physical force. ${ }^{44}$

The problem of 'lifestyle anarchism' nonetheless remained on the agenda in 2003. A contributor to Akce recalled a 1995 debate started by American social theorist Murray Bookchin over Hakim Bey's concept of 'temporary autonomous zones': '[These are zones] where you might (!) live "freely" to some degree even though all around you, everything proceeds as usual, that is, power, capital and class function the way the ruling class want them to. ${ }^{45}$ Others invoked the principles of the workers' rights movement:

'Lifestylism,' that is, adopting anarchism as a lifestyle, might be good for the person concerned, but it doesn't solve or change anything because those in power and the state are happy to let you believe you're living your 'life as a free spirit' and they're even ready to support you in that... . In fact, power and authority often feed off rebellion and so leave room for some resistance. They simply let a certain percentage (roughly $5 \%$ ) of people live rebelliously on the fringes of society without any obvious suppression and tolerate their revolutionary thinking. ${ }^{46}$

The same issue of Akce brought news of a Roma youth who had opened 'friendly fire' on an antifascist who looked like a skinhead. This report was supposed to highlight the dangers of adopting subcultural traits. ${ }^{47}$

By the second half of the 200os, however, AFA had acknowledged the importance of new sources of subcultural support. At the same time, it noted that the problems of 'isolation and the impossibility of reaching the broader public'48 were becoming paramount. During this period, AFA organizers abandoned their revolutionary antifascist message and began to limit their demonstrations and counter-demonstrations, complaining that based on experience these activities were too much effort for too few benefits. Instead, the group focused

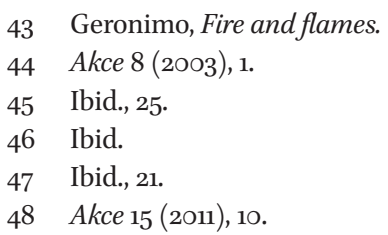


on organizing their four annual May Day festivals with music and political speeches. ${ }^{49}$ By the end of the decade, it had also arranged an exhibition titled 'Victims of Neo-Nazism' that toured to Lidice, the village near Prague that the Nazis had burned to the ground in 1942 to avenge the assassination of Acting Reich-Protector of Bohemia and Moravia Reinhard Heydrich. In this way, a link was forged with an earlier version of the Czech antifascist movement.

AFA's reinvention as an organization with an agenda that was more open and less focused on revolutionary antifascism coincided with the reinvigoration of the far right in the late 200os. A new group of Autonomous nationalists replaced the older generation of NO activists. While mainstream anti-Roma campaigns between 2008 and 2013 and the economic downturn created the macropolitical conditions to re-energize the far right, AFA doubled down on the problem of subcultural infiltration. ${ }^{50}$ Attention shifted to a new farright strategy that was radically different from the violent confrontation tactics of the early 199os. Starting in the early 20oos, the far right appropriated black metal as 'national socialist black metal. ${ }^{51}$ At the same time openly far right activists joined football hooligan 'firms' 52 and even developed national socialist hip-hop. ${ }^{53}$ AFA's response was to launch its own brand of 'Antifa hooliganism ${ }^{\prime 54}$ with activists adopting a militant look. This was a strategy that generated much confusion, as can be seen from this account of a 2003 May Day event in Bratislava: 'The [actual neo-]Nazis were attempting to hide near the cops, who were trying to protect them but were obviously taken aback and probably didn't even know what was going on (who wouldn't have been surprised since the antifascists had that classic Nazi look: boots, Lonsdale shirts, skinheads [?]) 55

AFA documented the far-right's appropriation of the symbols, aesthetic and general style of anarchists, ${ }^{56}$ especially the Black Bloc movement. The latter was associated with Palestinian head scarves, hardcore music (known in the far right version as 'hatecore' or 'h8core') and the straight-edge lifestyle (appropriated as 'h8 edge'). But it was not only the anarchists from whom the Autonomous

\footnotetext{
Antifa news 5 (2009); Antifa news 6 (2010).

Akce 16 (2012), 40.

Akce 5 (2002), 34-38.

Akce 9 (2004), 40.

Akce 17 (2012), 40-41.

Akce 14 (2011), 25-26.

Akce 8 (2003), 15 .

Akce 13 (2010), 3-7; 'Velká nazi vykrádačka,' Antifa.cz, 30 March 2010, 'https://www.antifa.cz/ content/velka-nazi-vykradacka, accessed July 2019.
} 
nationalists took symbols, fashion and music. They also adopted figures who were culturally significant to anti-communist Czech liberals in the postsocialist years including protest singer Karel Kryl. ${ }^{57}$ Another iconic figure who resonated strongly both with mainstream liberals and 'third position'-inspired nationalists was the Czech student Jan Palach, who had set himself alight in January 1969 to protest the Soviet occupation. Curiously, Palach was adopted by far right in Italy where he became an icon for neo-fascists, who cited him whenever the left invoked the self-immolation of Vietnamese Buddhist monks to protest the US involvement in Vietnam. ${ }^{58}$ The far right also mimicked other AFA practices, launching an anti-Antifa 'Smash the Reds' campaign and a (now defunct) White Media website ${ }^{59}$ where it maintained a list of 'traitors'.

By the mid-2010s, AFA's activities had been reduced to monitoring the far right. This reflected the general fading from view of not only almost all anarchist groups in the Czech Republic but much of the far right itself. The context for this was a steep rise in anti-migrant and anti-Islam positions among the general Czech population and the normalization of hate speech within mainstream politics. Czech far-right positions were increasingly taken up by major right- and left-wing parliamentary parties. As an AFA representative had observed of anti-Roma rallies half a decade earlier: "[L]iberal societies have learned to integrate elements of fascist regimes and can do this so adeptly that people actually welcome those elements. 60

Though AFA's membership had always been fairly diverse and the organization had evolved over time, it had consistently been part of an anti-authoritarian movement. As a result, its antifascism did not align neatly or self-evidently with any left-wing ideology or liberalism. Instead, AFA maintained strong anti-state positions, arguing that 'the state doesn't wish to destroy fascism but to keep it as a weapon of last resort against a growing social movement.' ${ }^{61}$ In adopting these stances, it simply ignored the fact that fascism was itself a social movement and indeed that under postsocialist conditions, it was far stronger than either the old or new left, anarchism or environmentalism. Staying true to their anarchist and autonomist roots, AFA members praised the decentralization of politics ${ }^{62}$ and endorsed direct strategic action. ${ }^{63}$ To some degree, they

57 Akce 16 (2012).

$5^{8}$ 'Moderní tvář neonacismu: Kryl, Palach a black bloc,' Antifa.cz, 3o March 2010, https://www. antifa.cz/content/moderni-tvar-neonacismu-kryl-palach-black-bloc, accessed July 2019.

59 'White Media', http://www.white-media.info/.

6o Akce 13 (2010), 20.

61 Akce 1 (2000), 1.

62 Akce 8 (2003), 33-34.

63 Ibid., 35 . 
also echoed environmentalist stances ${ }^{64}$ and wove anti-religious positions from different strands of anarchist thought: "The people [of Iran] must free themselves of mental bondage and the shackles of the Quran. Freedom of thought! Freedom to those who've seen through the absurdity of religious slavery! 65

Such a stance would scarcely be imaginable by the mid-2o10s when AFA opposed itself to the widespread Islamophobia in mainstream Czech politics. A decade earlier, however, during the 2005 banlieue riots in France, Akce reprinted a Fédération anarchiste text that implicitly attacked radical Islamism: 'Yes, there are reasons to rebel, but burning cars (which sometimes belong to people just as poor as the ones who burn them) and staging attacks without choosing the right targets does not harm [the system] and, on the contrary, encourages a narrow focus on identity (whether nationalist or religious). 66 Radical (anti-)Islamism was, however, never more than a topic imported into the Czech context from the old EU member states.

What was more fundamental for AFA was the view that the main enemy went beyond the far right and the state. As part of a grassroots anti-authoritarian movement, it endorsed anti-totalitarianism, adopting positions that were not only anti-Bolshevik but more generally anti-Marxist and anti-communist. This radical rejection of 'Red fascism' 67 and the 'authoritarian left' 68 can only be understood in the postsocialist context where the left had been severely tarnished by its ties to state socialism. For younger people especially, the left had lost all credibility, a problem that was not resolved even during the post2008 economic crises when the far right proved far more successful in reaching important segments of the population. In some of its statements, AFA stressed the similarities between the far right and Bolshevism and opposed itself equally to both political poles: 'AFA is open to anyone who wants to actively participate in the struggle against fascism, Nazism and Bolshevism in all their forms. ${ }^{69}$

On this count, AFA's stances reflected the de-legitimization of communist thought in the postsocialist space. Here there was a stark contrast with many other European countries where libertarian and left-wing communism remained integral to antifascist positions. ${ }^{70}$ Along these lines, the

64 Akce 12 (2006), 16.

65 Akce $1(2000), 6$.

66 Akce 12 (2006), 28.

67 Akce 8 (2003), 29.

68 Akce 13 (2010), 21.

69 Ibid., 43.

70 Chamsy el-Ojeili and Dylan Taylor, 'Across and Beyond the Far Left: The Case of Gilles Dauvé,' Rethinking Marxism 28 (2016): 187-203, https://doi.org/10.108o/o8935696.2016.1168249. 
organization attacked other European antifascists for aligning too closely with Marxist-Leninists:

Unfortunately there were AFA members from Denmark and Sweden [at the Berlin congress]. We were quite surprised when they described their political orientation as 'Antifa,' which is ludicrous. On top of that, all their members are from the non-parliamentary left. I think this is quite widespread in Scandinavian countries. When we asked how they can agree with the Marxist-Leninists, we received the typical answer that they're also against capitalism. Some of the delegates were amused by our response that the neo-Nazis are also against capitalism. ${ }^{71}$

In fact, any affinity with the anti-capitalism of the far right would later be explicitly dismissed by AFA, which distinguished the far right's stance as 'primitive anti-capitalism' similar to its 'primitive anti-communism' and 'primitive Antiziganism. ${ }^{72}$ AFA's anti-capitalism was praised as an obviously more sophisticated version.

Critique of neoliberalism ${ }^{73}$ also began to appear in the pages of Akce in the early 20oos. ${ }^{74}$ While AFA's anti-capitalism was grounded in an ideological critique, it was not necessarily class-centered, though at the time when FSA and its anarcho-syndicalist class theory dominated the organization, such an analysis might have applied. AFA would go on to shed all its working-class associations, a trend also seen among German antifascists. ${ }^{75}$ During the early 200os, however, it rehearsed a Marxist-like position: anti-capitalism, it insisted, was a more comprehensive solution than militant antifascism. '[O]nly by achieving a truly egalitarian society can we destroy fascism as such. ${ }^{17}$

\section{United Against Fascism (Without the Communists)}

As the discussion so far has shown, there have been various shifts in the recent history of Czech antifascism, which AFA has dominated since 1996. After an

\footnotetext{
$71 \quad$ Akce 1 (2000), 4.

72 Akce 13 (2010), 8-9.

73 Annie McClanahan, 'Serious Crises: Rethinking the Neoliberal Subject,' Boundary 2: An International Journal of Literature and Culture 46, no.1 (2019): 103-132, https://doi. org/10.1215/o1903659-7271363.

74 Akce 8 (2003), 24; Akce 13 (2010), 12.

75 Copsey, 'Militant Antifascism,' 246.

76 Akce 1 (2000), 1.
} 
initial phase of grassroots violence, there was a turn to organized street blockades. This was followed by a period of summer camps typical of left-wing activist groups and finally the music festivals of the late 200os. Four annual May Day festivals held between 2008 and 2011 reflected a new AFA strategy to reach youth subcultures. The latter were seen as at once the locus of a fierce battle with the re-energized far right and a target audience with whom antifascism had already struck a chord in the early 199os.

AFA's May Day festival era coincided with the post-20o8 economic crises. While the economic fall-out was not as severe in the Czech Republic as it was in some other eastern and southern European countries, the rhetoric around these crises had a profound effect. Budget cuts scared many Czechs and especially harmed those on low incomes without stable employment. In the local popular imagination, the fiscal, economic and social crises were understood to have come from abroad, meaning the Eurozone and global markets. Nationalist movements, thus, saw a sharp rise in influence as they called for the shoring up of national borders. At the same time, the crises mobilized local activists. These individuals included not only Czech sympathizers with Occupy Wall Street and Movimiento $15-M$ but anarchists who saw the changing economic and social conditions as the basis for a new revolution. The records of AFA's May Day events clearly reflect these debates. The crises inspired a call to action: 'Today, as the illusion of a neoliberal paradise collapses, the knowledge that the ruthless pursuit of economic profit is not some true and indisputable ideal is increasingly inspired by more than well-established anarchist ideas. ${ }^{\prime} 77$

Though young Czechs had steadily lost interest in anarchism and begun to embrace the radical democratic but non-communist Left, the May Day festivals, born out of 'rage against the system, rage against the power of money,'78 drew many from across different subcultural scenes. In keeping with the AFA's culture of vigilance, precaution and suspicion, attendees of the music performances and debates were asked to refrain from taking photographs even in the 'kids' corners'. 'NO PHOTO' signs on site showed images of crossed-out cameras. Even more detailed explanations were given elsewhere: 'We ask everyone to respect the privacy of festival attendees and not buy any audiovisual recordings. Our professional photographers are in attendance and their photos will

77 'May Day - Festival proti rasismu o9,' Antifa.cz, 25 February 20o9, http://antifa.cz/content/ may-day-festival-proti-rasismu-o9, accessed July 2019.

78 'Report z May Day 2011,' Antifa.cz, 6 May 2011, http://www.antifa.cz/content/report-z-mayday-2011, accessed July 2019. 
be freely available on our website. ${ }^{79}$ Despite the ban on taking pictures, many unofficial photos of the May Day festivals can be found online today.

I attended the 2009 festival at a central Prague location that was still somewhat secluded, and thus, the perfect place for such an event. The site was an island accessible to the Smíchov neighborhood via a small bridge. With its diverse musical line-up, the event had the feel of a big summer festival encompassing different music scenes. Along with the music stage and a tent for debates between different Czech and international activists, many food stands filled the space. A report on the 2011 AFA May Day festival would stress the importance of these lifestyle and food choices: 'Of course, all the food at May Day was vegan. Vegan goulash, tofu burgers, hot dogs, pâté, pancakes, falafel, ice cream and various sweets and desserts were all available. Many people certainly enjoyed the soy milk in their (fair trade) coffee. Hopefully we succeeded in showing festivalgoers that it's possible to eat without harming animals. 80

In addition to promoting a vegan lifestyle, AFA's event planners focused on their guest list: the goal was to exclude political figures who might be controversial to a broad audience while also retaining credibility with the larger anti-authoritarian political scene. The 2009 festival had a surprising participant, Karel Schwarzenberg, then the Czech foreign affairs minister. Schwarzenberg, it was said, did not represent the Czech government at the festival but had rather come because of his own antifascist convictions, which had also led him to attend other anti-racist meetings. His presence at the festival was nevertheless hotly debated with AFA's decision to allow it being condemned by some visitors. The debate was perhaps even livelier two years later when AFA cancelled a scheduled talk by a member of the French-Belgian left communist organization Mouvement Communiste (MC). According to some of its Czech critics, MC was responsible for inciting class hatred, ${ }^{81}$ a charge that might seem somewhat curious in the context of an anarchist-backed festival. The potential presence of MC speakers had, however, clearly tested AFA's openness to activists who identified publicly as communist.

Similar fears of partnering with communists in the fight against fascism were expressed during Brno blokuje, another May Day 2011 event, which took place some two hundred kilometers to the south-east of Prague. Conceived in the spring of 2011, Brno blokuje was a broad civic initiative that responded

79 '1.5. MAYDAY festival 2010,' Antifa.cz, 8 April 2010, http://antifa.cz/content/15-maydayfestival-2010, accessed July 2019.

8o 'Report z May Day 2011.'

81 Mrtvola, Antifa, 'May Day Fest: Podněcování k nenávisti vi̊či skupině osob,' Punk.cz, 28 April 2011, http://www.punk.cz/index.asp?menu=3\&record=13229, accessed July 2019. 
to a planned neo-Nazi May Day march through Brno's Cejl neighborhood, known for its important Roma minority. This community protest followed a number of anti-racist actions with diverse support in Prague: they included a protest after the murder of Sudanese student Hassan Elamin Abdelradi in 1997 and again during a neo-Nazi march in the Jewish quarter on the anniversary of Kristallnacht in 2007. In Brno too, there had been several efforts to block neo-Nazi marches though both the number and range of blockade participants remained somewhat limited. In line with the central thesis of this study, the 2011 Brno blokuje highlighted AFA's disengagement from these kinds of actions, which it now left to civil society. Moreover, these developments illuminated the reality outside the Czech capital. The Brno blockade was revived in 2013, 2015 and 2017, the years when various far right organizations, including those with neo-Nazi leanings, held their annual marches in the second largest Czech city. In the intervening years, the same marches should have been held in Prague though some were cancelled for organizational reasons.

The far right's provocations in Brno came at a time when anti-Roma events were being staged elsewhere - in northern Bohemia. Brno blokuje was, thus, a mostly liberal-leftist response to the potential spread of inter-ethnic conflict to a new region (Brno and its surrounds). In contrast with the May Day festivals in Prague, Brno blokuje had no backing from AFA, which expressed its solidarity but distanced itself from the use of blockade tactics. ${ }^{82}$ The group reiterated its position that blockades involved much effort for very few rewards. In contrast, Brno blokuje's organizers stated: '[W]e believe a non-violent civic blockade is the appropriate response to the inability or unwillingness of the police, the courts, the authorities and politicians to effectively confront marches based on hate. ${ }^{83}$

The blockade was, then, not an AFA activity, and if there were any links to $\mathrm{AFA}$, then these remained concealed, at least publicly. Brno blokuje's organizers spoke instead of the event's apolitical nature: "This non-violent blockade of the neo-Nazi march is not being organized by any political party or movement and nor does it aim to promote one.'84 The fear of being linked to a political agenda, in fact, reflected a larger strategy. Brno blokuje aimed to establish a broad coalition of local supporters from many different political movements and subcultural groups. Those supporters included university students, Junáci [Czech scouts], environmentalists, young social democrats, non-parliamentary radical

82 '1.5.2011 Brno blokuje Tip!' Antifa.cz, 19 April 2011, http://antifa.cz/content/152011-brnoblokuje-tip, accessed July 2019 .

83 Press release, Brno blokuje 2011, author's personal archive.

84 Ibid. 
leftists, anarchists, punks and a relatively new demographic for local antifascist coalitions - hipsters. They also extended to a handful of influential rightwing liberal democrats who had distanced themselves from other political movements, in particular those 'waving red flags'. For their visual materials, the blockade's organizers sought out different colors to the black-and-red associated with AFA. Their goal was to produce a fresh, inspiring design that would appeal to a new generation of antifascists who did not necessarily have backgrounds in activism or subculture scenes.

The seemingly apolitical character of Brno blokuje may also have reflected a larger 'post-political' turn in Czech politics in the early 2010s. Many similar initiatives were launched in these years with the goal of not only opposing the far right but addressing a range of strictly locally defined topics. In the case of Brno blokuje, the local action had fairly strong support. Though the Cejl neighborhood was not totally spared the neo-Nazi parade in May 2011, the neo-Nazis were forced to change direction after being diverted from the main street, which had been blocked by demonstrators. Significantly, the blockade also took place without any major involvement from activists coming from elsewhere. Not only did AFA remain focused on its own May Day festival on the same day in Prague but few antifascist activists came from Bratislava and Vienna or nearby Moravian, Bohemian, Slovak and Austrian towns.

The blockade was, thus, rooted deep in Brno's civil society. This was, in fact, precisely the arrangement AFA called for at the time. It meant that AFA could concentrate on cultural events and the monitoring of far right activists, i.e. its main activities that had remained unchanged since its foundation. There was a steady decline in the number and impact of its interventions, and this was also presumably true of the number of its supporters.

\section{Conclusion}

The transformation of the Czech antifascist movement over the almost thirty years of its existence reflects profound changes in the associated anarchist and radical leftist movements. Czech antifascism arose as an immediate response to far-right street violence. As well as attacking Roma people, far-right skinheads targeted members of youth subcultures in the early 1990s. As a result, many participants in subcultural scenes took antifascist stands. The antifascist movement's subcultural alliances and concerns peaked in intensity in the early 199 os and again in the era of AFA music festivals in the early 20oos. Throughout this entire period, the strength of its class politics also varied but were never as intense and remained largely guided by theoretical discussions among Czech 
anarchists. In the early 199os, class-based arguments against capitalism had some traction, drawing force from discontent with the new postsocialist status quo and the unquestioning acceptance of stances based on struggles abroad. The tension between AFA's class-centered and subcultural dimensions grew in the late 199os with the introduction of new forms of cultural protest. This rift deepened in the early zooos after debates about 'lifestyle anarchism'. For a brief time, anti-globalization campaigns re-energized class consciousness, with issues of class prevailing over subcultural matters among antifascists. Nevertheless, a change in AFA's strategy in the second half of the 20oos caused it to embrace younger and more overtly anti-communist generations, with the result that class consciousness dissipated and subcultural matters prevailed. Starting in the mid-200os, AFA followed the lead of German antifascist groups that chose to focus on cultural activities like music, fashion and football while leaving physical confrontation to local initiatives. This trend continued even after the rather timid reintroduction of class as a topic in Czech public debates during and after the economic crises of the early 2010 .

\section{Acknowledgements}

This study is a result of the research funded by the Czech Science Foundation as the project GA ČR P410/20-24091S 'Brave New World:Youth, Music and Class in Czech Post-socialism'. 